\title{
Single Nucleotide Modification of VP2 Gene of Highly Virulent Infectious Bursal Disease Virus for Effective Expression Strategy in Tobacco
}

\author{
Siti-Hasmah $\mathrm{M}^{1}$, Hwe-San L ${ }^{2}$, Xiao-Ying $\mathrm{C}^{2}$, Massawe $\mathrm{F}^{2}$ and Abdul- \\ Rahman $0^{3}$ \\ ${ }^{1}$ Department of Science and Biotechnology, University Selangor, Malaysia \\ ${ }^{2}$ School of Biosciences, University of Nottingham Malaysia Campus, Malaysia \\ ${ }^{3}$ Institute of Bioscience, University Putra Malaysia, Malaysia
}

Research Article

Volume 2 Issue 1

Received Date: February 27, 2017

Published Date: March 22, 2017

DOI: $10.23880 /$ oajmb-16000116

*Corresponding author: Siti-Hasmah Mohtar, Department of Science and Biotechnology, University Selangor, Jalan Timur Tambahan, 45600 Bestari Jaya, Selangor, Malaysia, Tel: +60133957392; E-mail: hasmah@unisel.edu.my

\section{Abstract}

Plant viral-based expression system offers an alternative tool for the expression of various target proteins via stable transformation or transient expression in plants. In transient expression strategy, generation of in vitro viral transcripts through complete linearization of the recombinant vector containing the cloned gene is crucial to ensure the success of gene expression in plants. Hence, the present study was aimed to generate a modified VP2 gene of highly virulent Infectious bursal disease virus (hvIBDV) for effective cloning and expression of VP2 protein using an engineered Potato Virus X (PVX) vector as a gene delivery system in tobacco. Single nucleotide modification was employed at the Spel site of the VP2 gene through the substitution of adenine (A) to thymine (T) without changing the amino acid leucine. The modification had facilitated the generation of viral transcripts whereby the recombinant vector of PVX-VP2Mt was completely linearized through a single digestion at the SpeI site of the PVX vector. The modified VP2 gene was delivered and expressed in Nicotiana benthamiana via viral transcripts infection approach. Western blot analysis of plant crude extracts indicated detection of expected bands which confirmed the successful expression of a modified VP2 protein. The VP2 protein expression profile was determined by conducting a kinetic analysis analyzed by dot blot assay. The present study demonstrates the successful development of a modified VP2 gene of hvIBDV through a single nucleotide modification strategy which facilitate the expression of the VP2 protein using a Potato virus X expression system.

Keywords: Highly Virulent Infectious Bursal Disease Virus; VP2; Single Nucleotide Modification; Potato Virus X; Transient Expression 


\section{Open Access Journal of Microbiology \& Biotechnology}

\section{Introduction}

Infectious bursal disease virus (IBDV) is a double stranded RNA genome belongs to the genus of Avibirnavirus of the family Birnaviridae [1,2]. The virus causes severe immunosuppression in young chickens by destruction of immature B lymphocytes within the bursa of Fabricus [3]. The immunosuppression leads to an increased susceptibility to other pathogens [4]. As a consequence, the IBDV infection causes economic losses to the poultry industry in Malaysia and worldwide by causing a high rate of morbidity and mortality in an acute condition [5]. The IBDV genome consists of two segments; segment $A(3,245 \mathrm{bp})$ contains 2 open reading frames (ORFs) and segment $B(2,817 \mathrm{bp})$. The larger ORF of segment $\mathrm{A}$ is monocistronic and encodes a polyprotein that is auto-processed after several steps into mature VP2, VP3 and VP4 [6-9]. The ORF encodes a 109-kDa precursor polyprotein (N-VPX-VP4-VP3-C) which is selfcleaved to produce VPX (48 kDa), VP3 $(32 \mathrm{kDa})$ and the putative viral protease VP4 $(28 \mathrm{kDa})[7,8]$. In the mature virions, VPX is processed into VP2 (41 kDa). Among of all five recognized genes in IBDV genome, the VP2 gene has been identified as the most suitable gene for identification of IBDV because it carries the major antigenic site for all IBDV strains responsible for eliciting neutralizing antibodies [10]. The hyper variable region found in the VP2 gene contains amino acid sequence that associated with the virulence properties of IBDV strain.

The VP2 of IBDV is a structural protein located on the capsid surface and contains conformation-dependent epitopes that are responsible for eliciting neutralizing antibodies [11]. The VP2 is considered the highest polypeptide constitutes that makes up more than $50 \%$ of the IBDV virion protein. The protein composed of approximately 494 amino acid residue long and has been identified as the main host protective antigen carrying the major neutralizing epitopes [7,10-12]. VP2 contains the antigenic region responsible for the induction of neutralizing antibodies and for serotype specificity which identified as the host protective antigen [10]. These properties make VP2 as a suitable target protein for the development of subunit vaccines. The VP2 gene has been expressed in variety of expression systems including prokaryotic system [13], yeast [14] and animal viralbased systems [15-18], baculovirus systems $[19,20]$ and plant viral-based system [21].

Plants have been recognized as an alternative system for the production of subunit vaccine either by stable transformation or via virus-mediated transient expression strategy. Transient expression using plant viruses involves integration of the genetic material encoding the immunologically active protein or peptide into the genome of a plant virus and uses that to infect the plants. The protein or peptide is then expressed either on the surface of the virus particle as a fusion epitope with the viral coat protein or as an autonomous protein produced as a by-product of the virus infection. Potato virus X (PVX), a member of Potexvirus has been developed as a viral vector for gene delivery and expression of various target proteins or peptides fused to the viral coat protein in plants [22-24]. The advantages of employing PVX vector as gene delivery system over other plant viral vector are its relative stability and mechanically transmissible [25]. Potato virus X-based transient expression vectors are available in three formats. The first uses a duplicated sub-genomic promoter to drive exogenous gene expression [23]. In the second, foreign proteins are expressed as $\mathrm{N}$-terminal coat protein (CP) fusions. The exogenous protein could be fused directly to the $\mathrm{N}$-terminus of $\mathrm{CP}[22]$ or it could be linked to the CP via the Foot and Mouth Disease virus 2A catalytic peptide [26]. In the third format, the CP sub-genomic promoter drives the transcription of a bicistronic mRNA containing both the foreign gene and $\mathrm{CP}$ gene, separated by an internal ribosome entry site [27].

A number of approaches have been employed for the generation of modified sequence in cloned gene. In general, there are three approaches of side-directed mutagenesis which involve PCR with modified primers, primer extension and inverse PCR. In modified primer approach, PCR primers are designed to contain the desired nucleotide changes including nucleotide substitutions, additions or deletions. As the primers are extended in the PCR, the resulting amplification product incorporates the mutation and replaces the original sequence. Site-directed mutagenesis by primer extension has been described previously [28] and involves incorporating mutagenic primers in independent, nested PCRs to ultimately combine them in the final product. Inverse PCR uses primers oriented in the reverse direction to amplify a region of unknown sequence [29]. Mutagenesis can be used to change cloned sequences using a technique adapted from the inverse PCR method [30]. In this method, the entire circular plasmid is amplified and a sequence is deleted, changed or inserted. Current method of side directed mutagenesis (SDM) employs PCR using oligonucleotide primer pairs that carry the desired mutation [31]. The SDM method involves two PCR reactions run in parallel with each one employs forward and reverse primers. The parental plasmid containing cDNA insert was amplified first in two 
separate PCR reactions containing either forward or reverse primer. At the end of the PCR, both reactions are combined and the methylated parental plasmid DNA was digested with restriction enzyme (DpnI) and the mutated plasmids are subsequently transformed into host cells.

Delivery of gene using plant viral-based expression vector in plants can be achieved by two approaches which are viral infection method and agroinfection method. The viral infection can be initiated by mechanical inoculation of infectious viral particles on leaves using an abrasive material such as carborundum. Viral replication rapidly amplifies the incorporated genes which results in high expression levels of the recombinant protein throughout the whole plant [32]. In transient expression system, in vitro viral transcripts are generated by linearization of the recombinant plasmids using restriction enzyme digesting at the unique site of the vector. An engineered PVX vector designated as pP2C2S [24] contains two restriction sites of SpeI and SphI for the purpose of vector linearization. Previous studies have shown that most of researchers employed SpeI restriction enzyme for linearization of the recombinant pP2C2S vector compared to $S p h I[33,24]$. Digestion by SpeI enzyme was found more efficient due to its position which is lies immediately downstream of the 3 ' poly(A) tail of the infectious clones [34]. The internal coding sequence of hvIBDV VP2 gene contains a single recognition site of SpeI at the nucleotide position of 1050 to 1055. The use of SpeI restriction enzyme is only applicable if the SpeI recognition site on the VP2 coding region is disrupted into a non-functional recognition site. Therefore, the present study was undertaken to construct a modified VP2 gene of hvIBDV at the SpeI site via single nucleotide modification strategy and cloned the VP2 complete genome of approximately $1.4 \mathrm{~kb}$ onto a plant viral based expression vector of PVX for the expression of VP2 protein in tobacco. Generation of a modified VP2 gene at its Spel restriction site would facilitate the linearization of the recombinant PVX vector for generation of in vitro viral transcripts. The efficacy of PVX vector as a gene delivery system for the expression of VP2 protein in tobacco was evaluated.

\section{Materials and Methods}

\section{Amplification and Cloning of hvIBDV VP2 Gene}

Total RNA extraction of a Malaysian strain of hvIBDV and amplification of VP2 gene has been described in previous study [35]. The VP2 gene was amplified using a set of primers designated as VP2F1 (5'GGGATATCATGACAAACCTGCAAGATCAAACCCAAC-3') and VP2R1 (5'-GGGTCGACTTAGGCCCGGATTATGTCTTTG-
3'). Both forward and reverse primers were incorporated with restriction enzyme sites of EcoRV and Sall at 5' region, respectively to facilitate the cloning of VP2 gene. The amplified VP2 gene was purified and subsequently cloned into pCR2.1-TOPO TA cloning vector (Invitrogen, USA). Plasmid extraction was carried out using GeneAll Exprep ${ }^{\mathrm{TM}}$ Plasmid Quick (GeneAll Biotechnology, Korea) following the protocol described by the manufacturer. Restriction enzyme analysis of the recombinant pCR2.1:: VP2 plasmids was conducted using EcoRI restriction enzyme to confirm the presence of VP2 gene.

\section{Single Nucleotide Modification of VP2 Gene}

Single nucleotide modification of the VP2 gene involved amplification of DNA strand of recombinant pCR2.1::VP2 plasmid using a forward primer (VP2M: 5'CGTCCCGTCACACTTGTAGCCT-3') designed according to the VP2 sequence at nucleotide position of 1039 to 1060 which contained the modified restriction enzyme site of SpeI (ACTTGT). The mutated SpeI site was generated at nucleotide position of 1053 from adenine (A) to thymine (T) without changing the amino acid leucine (Figure 1). Modification strategy of VP2 gene was summarized in a schematic diagram as indicated in Figure 2.

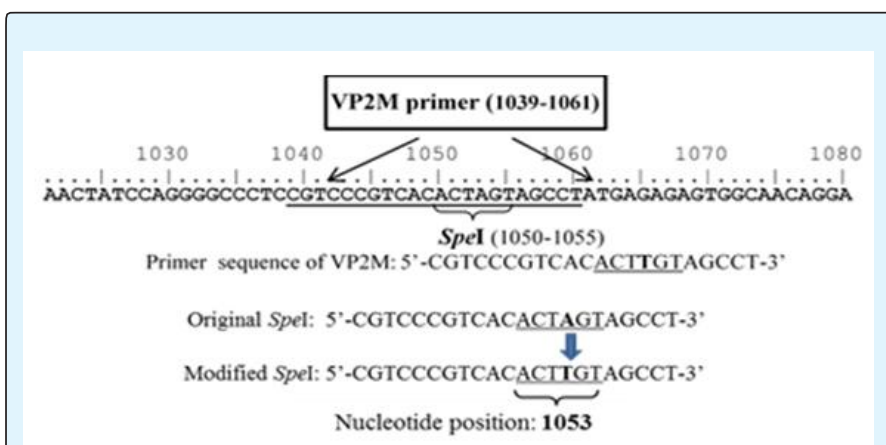

Figure 1: Nucleotide sequence of VP2M primer generated based on the sequence of VP2 gene at position 1050 to 1055 . The modified SpeI sequence possesses nucleotide substitution from adenine (A) to thymine (T) at the nucleotide position of 1053.

\section{Modification of SpeI Site of VP2 Gene by PCR1 Amplification}

Single nucleotide modification of SpeI site was performed by amplifying the whole plasmid sequence of pCR2.1::VP2 using a primer of VP2M as described previously. PCR reaction was prepared in $50 \mu \mathrm{l}$ reaction volume containing the following components: $25 \mathrm{ng}$ of pCR2.1::VP2 plasmid DNA, $0.5 \mu \mathrm{M}$ of VP2M, $2 \mathrm{U}$ of Taq 
polymerase (Invitrogen, USA), 1X PCR buffer, $0.2 \mathrm{mM}$ of dNTP mixture, $1.5 \mathrm{mM} \mathrm{MgCl}_{2}$ and topped up with distilled water. PCR amplification was started with predenaturation at $94^{\circ} \mathrm{C}$ for 5 minutes, then followed by 25 cycles of denaturation at $94^{\circ} \mathrm{C}$ for 45 seconds, annealing at $56^{\circ} \mathrm{C}$ for 30 seconds and extension at $72^{\circ} \mathrm{C}$ for 15 minutes. Final extension was carried out at $72^{\circ} \mathrm{C}$ for 10 minutes. Purification of the PCR product was performed using MEGA quick-spin PCR and Agarose Gel DNA Extraction System (Intron Biotechnology, Korea) following the manufacturer's protocol.

\section{PCR2 Amplification on Plus Strand Modified VP2 Gene}

Second PCR was conducted using the purified ligation product previously amplified from the first PCR as a template in order to generate the reverse strand of pCR2.1::VP2 DNA with modification site. In this step, a set of primer consisting of forward (VP2F1) and reverse (VP2R1) primers was used to amplify the VP2 gene. Fifty microlitres of PCR reaction mixture was prepared as follow: 150 to $250 \mathrm{ng}$ of purified ligation products, $0.5 \mu \mathrm{M}$ of VP2F, $0.5 \mu \mathrm{M}$ of VP2R1, $1.25 \mathrm{U}$ of i-Pfu polymerase (Intron Biotechnology), 1X i-Pfu buffer, $0.8 \mathrm{mM}$ dNTP mixture and made up with distilled water. PCR master mix was prepared as above mentioned for 2 sets of samples, positive control and negative control. PCR reaction was set at $94^{\circ} \mathrm{C}$ for 2 minutes as predenaturation step and followed by 25 cycles of denaturation at $94^{\circ} \mathrm{C}$ for 20 seconds, annealing at $65^{\circ} \mathrm{C}$ for 1 minute and extension at $72^{\circ} \mathrm{C}$ for 20 minutes. Final extension was carried out at $72^{\circ} \mathrm{C}$ for 5 minutes. The PCR products of VP2 gene were purified using MEGA quickspin PCR and Agarose Gel DNA Extraction System (Intron Biotechnology, Korea) for further analyses.

\section{Identification of Modified VP2 Gene by SpeI Digestion}

The purified VP2 gene from second PCR was screened by SpeI digestion to select VP2 gene with modified SpeI site. The digestion reaction was prepared in $50 \mu \mathrm{l}$ of reaction mixture and prepared as follow: $10 \mathrm{U}$ SpeI restriction enzyme (Vivantis, USA), 1X V2 restriction enzyme buffer, $1 \mu \mathrm{g}$ of PCR purified product and filled with distilled water. The positive (unmodified VP2 fragments from PCR2) and negative controls were also prepared in this reaction. Reaction mixture was incubated at $37^{\circ} \mathrm{C}$ for 3 hours. Then, the digestion reaction mixture was analyzed by $1 \%$ agarose gel without addition of SYBR $\mathrm{Safe}^{\mathrm{TM}}$ (Invitrogen, USA). Positive, negative and $10 \mu \mathrm{l}$ of SpeI digested PCR products were mixed with SYBR Safe ${ }^{\mathrm{TM}}$ and 6X DNA loading dye (Fermentas Life Science, Canada) before loaded into well of $1 \%$ agarose gel. Forty $\mu$ l of digested PCR products were only mixed with 6X DNA loading dye and loaded directly into well of $1 \%$ agarose gel without SYBR Safe ${ }^{\mathrm{TM}}$. After electrophoresis, the bands which were not digested by SpeI restriction enzyme were identified and selected for DNA purification.

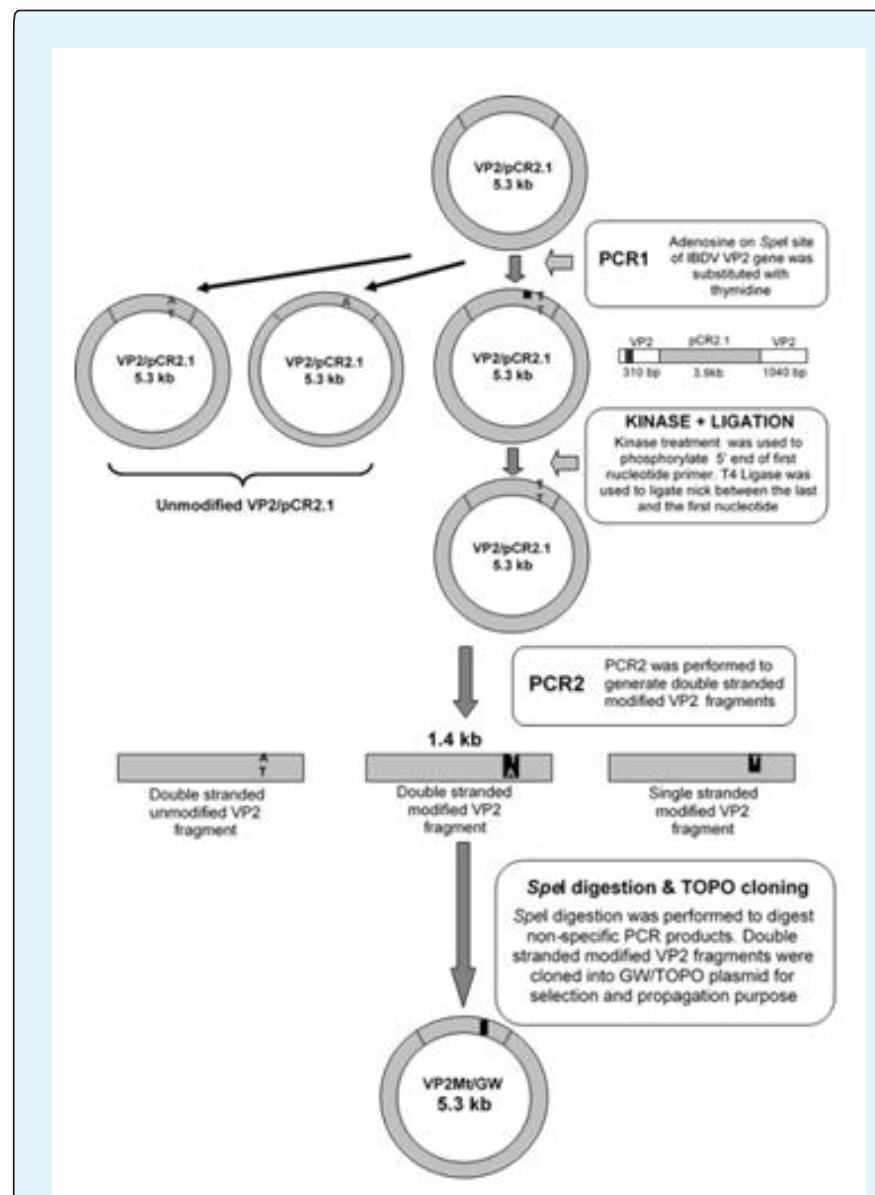

Figure 2: Schematic diagram showing the flow of procedure involved in single nucleotide modification of SpeI site of hvIBDV VP2 gene.

\section{Transformation of Modified VP2 Gene into $E$. coli}

Ligation of the PCR fragments with TOPO cloning vector for the cloning purpose can be facilitated by the addition of adenosine at 3 ' end of PCR fragments. Therefore, overhang ' $A$ ' was added to the 3 ' end of purified PCR fragments following TOPO cloning steps. Reaction mixture was prepared as follow: gel-purified SpeI-digested PCR products, $0.5 \mathrm{U}$ Taq polymerase, 1X 
PCR buffer, $0.2 \mathrm{mM}$ dNTP mixture, $1.5 \mathrm{mM} \mathrm{MgCl}$ and filled up with water and incubated at $72^{\circ} \mathrm{C}$ for 10 minutes. After additional of overhang 'A', the gel-purified SpeI digested product was cloned into pCR@8/GW/TOPO (Invitrogen, USA) (Figure 3). The cloning reaction mixture was set up as follow: $4 \mu \mathrm{l}$ of DNA product, $1 \mu \mathrm{l}$ of salt solution, $0.6 \mu \mathrm{l}$ of TOPO ${ }^{\circledR}$ vector and filled up with distilled water. The reaction mixture was incubated at room temperature for 15 minutes and then transferred onto ice. Thereafter, the recombinant plasmid designated as pCR@8/GW::VP2Mt was then transformed into One Shot ${ }^{\circ} \mathrm{TOP} 10$ chemically competent cells for propagation purpose. The transformed competent cells in SOC medium were spread onto LB (Luria Bertani) agar plates containing $100 \mathrm{mg} / \mathrm{L}$ spectinomycin and incubated at $37^{\circ} \mathrm{C}$ overnight.

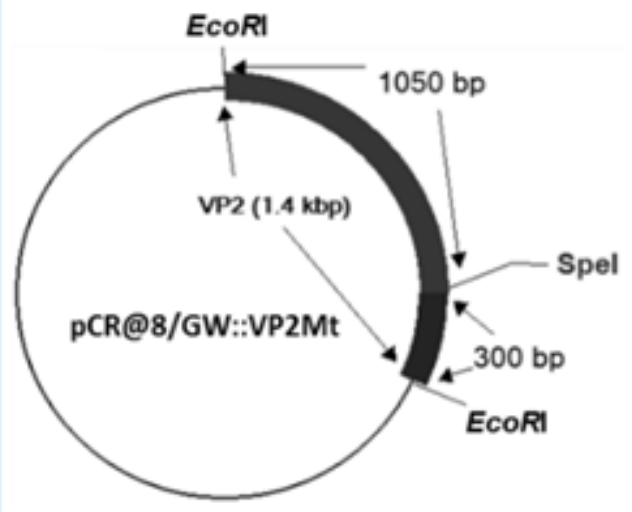

Figure 3: Schematic diagram of recombinant pCR@8/GW::VP2Mt plasmid

\section{Characterization \\ of \\ Modified pCR@8/GW::VP2Mt Recombinant Plasmids}

Single colonies grown on the agar plates were picked and screened for positive clone of pCR@8/GW::VP2Mt by PCR amplification using VP2F1 and VP2R1 primers. Preparation of PCR reaction mixture and thermal cycle program has been described previously. The positive clones were propagated in $10 \mathrm{ml}$ of LB broth containing $100 \mathrm{mg} / \mathrm{L}$ spectinomycin for plasmid extraction. Extracted recombinant plasmids were analyzed for the modified VP2 gene insert by digestion with SpeI and EcoRI enzymes (Vivantis, USA). For digestion analysis, $20 \mu \mathrm{l}$ of reaction mixture was prepared with $5 \mathrm{U}$ restriction enzymes (Spelor EcoRI), restriction enzyme buffer, $200 \mathrm{ng}$ of pCR@8/GW::VP2Mt recombinant plasmid and made up with distilled water. Digestion reaction mixture was incubated at $37^{\circ} \mathrm{C}$ for $3-4$ hours and analyzed by $1 \%$ agarose gel electrophoresis.

\section{Restriction Enzyme Digestion of PCR Amplified Products of VP2Mt And PVX Vector}

The potato virus $\mathrm{X}$ (PVX) vector designated as pP2C2S (24) used in this study was kindly provided by Prof. Dr. David Baulcombe from the University of Cambridge, UK. The PVX vector was propagated in XL1-Blue E. coli strain for plasmid extraction. The amplified VP2Mt gene together with pP2C2S vector was digested with EcoRV and Sall enzymes. The digestion reactions were prepared as described in previous section and the mixtures were incubated at $37^{\circ} \mathrm{C}$ for 3 hours. After the incubation, the digested VP2Mt gene and the pP2C2S vector were purified and used in the following ligation process.

\section{Cloning and Verification of PVX::VP2Mt Recombinant Vectors}

The digested VP2Mt gene was ligated with digested pP2C2S vector to form a construct of recombinant PVX::VP2Mt vector as indicated in Figure 4. The ligation reaction was prepared in $40 \mu \mathrm{l}$ reaction volume which consists of 10X ligation buffer, $2 \mathrm{U}$ of T4 DNA ligase (New England Biolabs, UK), 100 ng PVX vector, 500 ng VP2 gene variants and filled up with distilled water. The ligation reaction mixtures were incubated at $25^{\circ} \mathrm{C}$ for 2 hours and transformed into XL1-Blue competent cells. The transformed bacteria were spread on to LB agar plates containing $50 \mu \mathrm{g} / \mathrm{ml}$ ampicillin and incubated at $37^{\circ} \mathrm{C}$ for 16 hours. The presence of VP2Mt in the PVX vectors was confirmed by digesting the extracted recombinant PVX::VP2Mt vectors with EcoRV, SalI and SpeI enzymes. The restriction enzyme analysis was carried out in $15 \mu \mathrm{l}$ reaction mixtures containing $1 \mu \mathrm{g}$ of recombinant PVX::VP2Mt, 1X RE buffer, $10 \mathrm{U}$ of restriction enzymes (EcoRV and SalI) and deionized distilled water. The digestion reaction mixture was incubated at $37^{\circ} \mathrm{C}$ for 3 hours and analyzed by $1 \%$ agarose gel electrophoresis.

\section{Linearization of Recombinant Empty PVX and PVX::VP2Mt Vectors}

The empty PVX vector together with the recombinant PVX::VP2Mt vector was digested with SpeI restriction enzymes in order to produce a linearized vector. The digestion reaction was prepared in $15 \mu \mathrm{l}$ reaction mixtures containing $1 \mu \mathrm{g}$ of recombinant PVX vector, $1 \mathrm{X}$ RE buffer, $5 \mathrm{U}$ of SpeI enzyme and deionized distilled water. The digestion reaction mixture was incubated at $37^{\circ} \mathrm{C}$ for 4 hours and the reaction was terminated by adding $0.75 \mu \mathrm{l}$ of $0.5 \mathrm{M}$ EDTA, $1.5 \mu \mathrm{l}$ of $5 \mathrm{M} \mathrm{NH} 4$ acetate and $30 \mu \mathrm{l}$ of ethanol. All the components were mixed well with the digestion reaction and the mixture was chilled at $-20^{\circ} \mathrm{C}$ for 15 minutes. Then the mixture was centrifuged at 
$14,000 \mathrm{rpm}$ at $4^{\circ} \mathrm{C}$ to pellet the DNA. The DNA pellet was resuspend in distilled water at a concentration of 0.5 to $1.0 \mathrm{\mu g} / \mu \mathrm{l}$ and subsequently used for in vitro transcription.

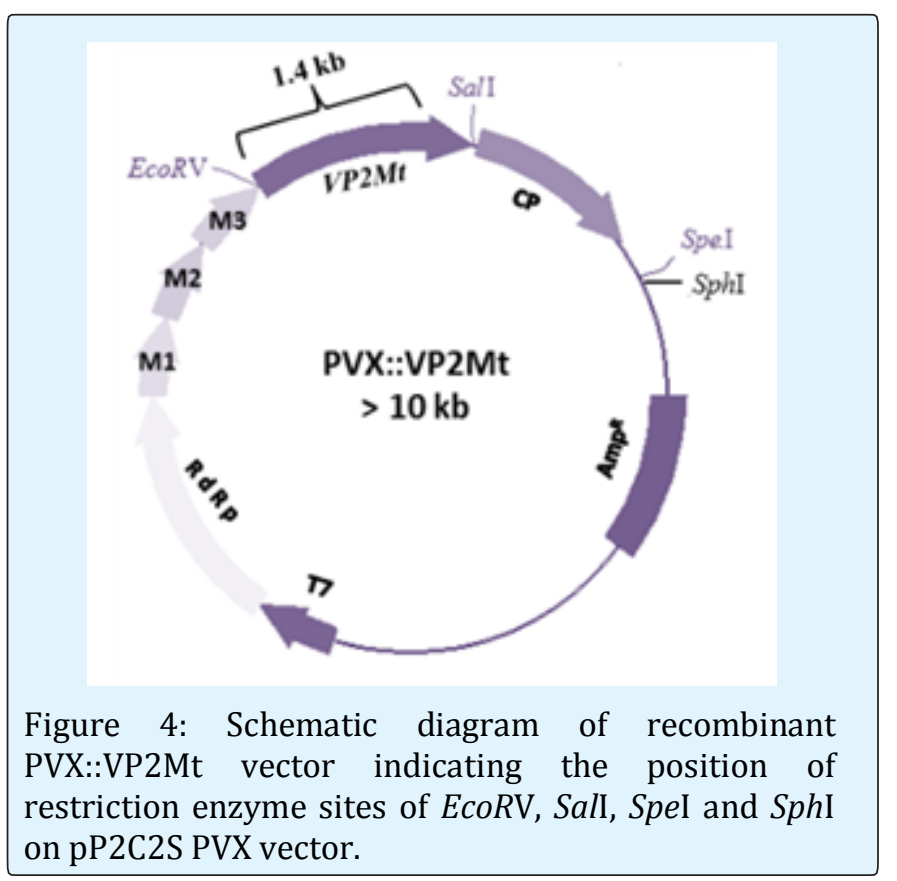

\section{In vitro Transcription of PVX Viral Transcripts}

The viral transcripts of empty PVX and recombinant PVX::VP2Mt vector were generated using Ambion mMESSAGE mMACHINE ${ }^{\circledR}$ Kits (USA) which were designed for the in vitro synthesis of capped RNA. Capped transcription assembly reactions consist of nuclease free water, $1 \mathrm{X}$ reaction buffer, $1 \mathrm{X}$ NTP/CAP, $2 \mu \mathrm{l}$ of enzyme mix and $1.0 \mu \mathrm{g}$ of linearized template DNA and made up to $20 \mu \mathrm{l}$ with nuclease free water. The reaction mixture was mixed thoroughly and incubated at $37^{\circ} \mathrm{C}$ for 15 minutes for cap incorporation. Then, $0.3 \mathrm{mM}$ GTP was supplemented into the reaction mixture and incubated at $37^{\circ} \mathrm{C}$ for 1 hour. After the incubation, $1 \mu \mathrm{l}$ of TURBO DNase was added into the reaction mixture to remove the remaining template DNA. The mixture was mixed well and incubated at $37^{\circ} \mathrm{C}$ for another 15 minutes. After the incubation was complete, $30 \mu \mathrm{l}$ nuclease-free water and $30 \mu \mathrm{l}$ Lithium Chloride ( $\mathrm{LiCl}$ ) precipitation solution were added into the reaction mixture to stop the reaction and precipitate the RNA.

\section{Mechanical Inoculation of Chimeric PVX Viral Transcripts in Nicotiana benthamiana}

The capped viral transcripts of empty PVX and PVX::VP2Mt of amount between 0.1-0.5 $\mu \mathrm{g}$ were mechanically inoculated in the presence of silicon carbide (400 mesh) on two fully expanded leaves by gently rubbing the leave surface. The inoculated plants were maintained in a growth room at $25^{\circ} \mathrm{C}$ with supplementary of lighting to give a 12 hour photoperiod. The progression of viral infection symptoms was assessed on a daily basis.

\section{Total Plant RNA Extraction and Analysis of VP2 Gene Expression}

The infected tobacco leaves inoculated with PVX::VP2 viral transcripts were harvested at 2, 4 and 8 days post infection (dpi) for extraction of total RNA. The leaves from plants inoculated with empty PVX and non-inoculated plants were also harvested for RNA extraction to serve as negative controls. The extraction was performed using TRIZOL® LS Reagent (Invitrogen, USA) following protocols recommended by the manufacturer. Approximately, $1 \mu \mathrm{g}$ of extracted RNA from uninfected plants and plants inoculated with empty PVX and PVX::VP2Mt were analyzed in $1.5 \%$ agarose gel electrophoresis. About 50 to $100 \mathrm{ng}$ of synthesized cDNA was subsequently used for PCR amplification of the VP2 gene for the analysis of gene expression.

\section{Western Blot Analysis of Total Soluble Protein}

The extracted proteins were separated by SDS-PAGE before transferred onto a transfer membrane in Western blotting. Following electrophoresis, the separated proteins were transferred onto a nitrocellulose membrane (Millipore, USA) using a wet-blotting transfer apparatus of XCell $\mathrm{II}^{\mathrm{TM}}$ Blot Module (Invitrogen, USA). Then, the protein transferred membranes were conjugated with primary and secondary antibodies for detection of VP2Mt protein. Western blot analysis was conducted according to the standard protocol describe previously [36]. The membrane was incubated in blocking solution, followed by primary antibody of polyclonal antiIBDV (Abcam, USA) at dilution of 1:5000 and secondary antibody of polyclonal goat to chicken IgY conjugated with horseradish peroxidase (HRP) (Abcam, USA) diluted at 1:10,000 in PBS-T. The presence of VP2Mt protein was detected by incubating the membrane in either TMB substrate (Pierce, USA) or by chemiluminescent reagents. In chemiluminescent detection, the membrane was developed using Super Signal West Pico Chemiluminescent Substrate (Pierce) following the protocol recommended by the manufacturer. A working solution was prepared by mixing equal parts of the Stable Peroxide Solution and the Luminol/Enhancer Solution. The working solution was poured onto the blotted membrane and incubated for 5 minutes. The blot was 
exposed with the appropriate light for chemiluminescent detection between 5 to 20 minutes exposure time using Bio Imaging System (BIO-RAD, USA) to develop the signal.

\section{Kinetic Analysis of VP2 Expression}

Kinetic analysis was carried out to determine level of VP2 protein expression in $N$. benthamiana on particular days. $N$. benthamiana of 2 months old were selected for the kinetic analysis of VP2 expression. In this analysis, 0.5 $\mu \mathrm{g}$ of viral transcripts of PVX::VP2Mt or empty PVX was used to inoculate 2 fully expanded leaves for each plant. Leaves surface was first dusted with small amount of carborandum and 20-30 $\mu \mathrm{l}$ of diluted viral transcripts $(0.5$ $\mu \mathrm{g})$ was applied onto leaves surface. The inoculated viral transcripts were gently rubbed together with carborandum on the leaves surface. Inoculated plants were harvested on day $2,4,6,8,10,15,20$ and 30 post inoculations. Four replicates of tobacco seedlings inoculated with the PVX::VP2Mt, 1 mock tobacco seedling infected with empty PVX and non-inoculated plants were harvested on each indicated days. The leaves harvested from day 2 to 30 post inoculation were extracted for total soluble protein from either fresh or frozen leaves of inoculated and non-inoculated tobacco plants. Initially, leaf samples were ground into powder form in liquid nitrogen. Then, $0.5 \mathrm{~g} / \mathrm{ml}$ protein extraction buffer containing $50 \mathrm{mM}$ Tris- $\mathrm{HCl}, 150 \mathrm{mM} \mathrm{NaCl}, 0.2 \%$ Triton X100 and $1 \mathrm{mM}$ phenylmethylsulfonyl fluoride (PMSF) were added. The soluble protein was precipitated in 4 volumes of $10 \% \mathrm{TCA} /$ acetone, chilled at $-20^{\circ} \mathrm{C}$ for 1 hour and centrifuged at $15,000 \mathrm{~g}$ for $10 \mathrm{~min}$ at $4^{\circ} \mathrm{C}$. The plant extracts were further analyzed by dot blot assay.

\section{Dot Blot Assay of Total Soluble Proteins}

A nitrocellulose membrane (Invitrogen, USA) was cut into appropriate size and soaked in Tris-buffered saline (TBS) buffer for 10 minutes. Concentrated protein samples between 4 to $5 \mu \mathrm{l}$ containing approximately $2 \mu \mathrm{g}$ of total soluble protein from inoculated and noninoculated plant extracts were spotted onto the nitrocellulose membranes. The membrane was dried at room temperature until all samples completely penetrated the membrane. Then, the membrane was incubated in blocking solution containing 5\% skimmed milk in phosphate buffer saline (PBS) for 1 hour to block non-specific site of the membrane. Similar procedure was applied for detection of the expressed VP2 protein using primary and secondary antibody as described previously under the section of Western blot analysis. After washed three times in PBS-T and once with $1 \mathrm{X}$ PBS, the membrane was then incubated in TMB substrate (Pierce,
USA) for few minutes until the desired development was achieved. The substrate reaction was stopped by washing the blot in distilled water. The membrane was air-dried at room temperature and the developed reaction was captured in Bio Imaging System using Quantity One program (BIO-RAD, USA).

\section{Results and Discussions}

\section{Characterization of Positive Clones of Recombinant Plasmid}

Restriction enzyme analysis on the recombinant pCR2.1::VP2 plasmids demonstrated two separated bands of $3.9 \mathrm{~kb}$ derived from the pCR2.1/TOPO plasmid and 1.4 $\mathrm{kb}$ DNA of VP2 fragment when digested with EcoRI enzyme (Figure 5).

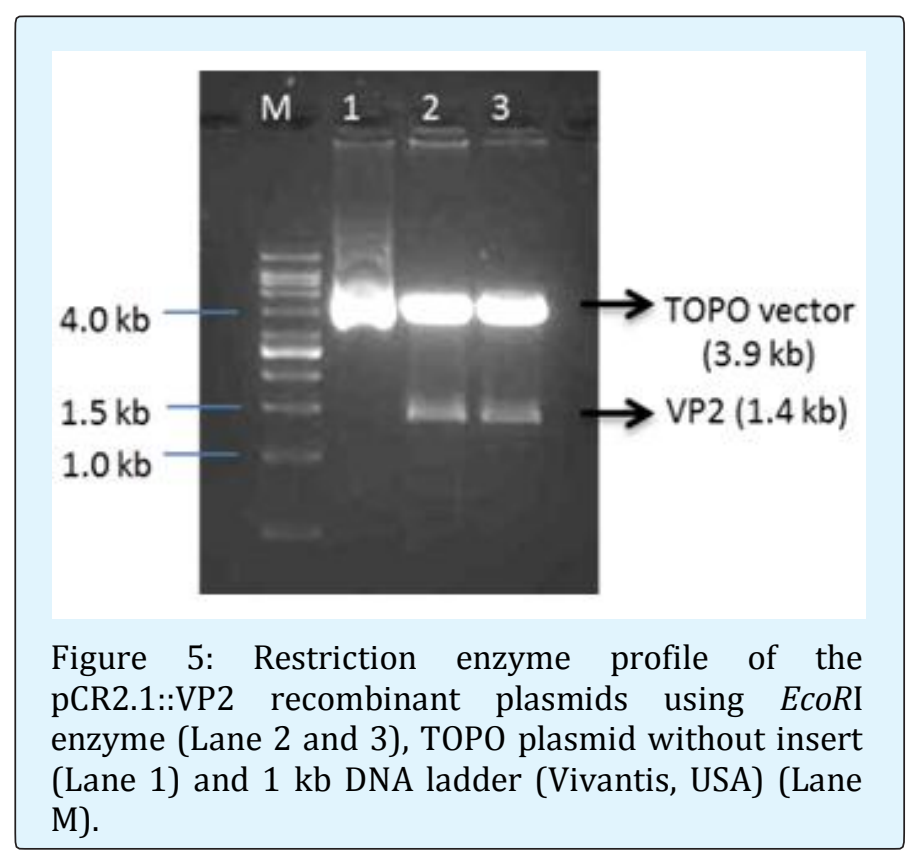

\section{Modification of SpeI Site of VP2 Gene and Identification of the Modified VP2 Gene}

PCR amplification of modified pCR@8/GW::VP2Mt DNA produced different combinations of PCR products which consist of double strand modified, double strand unmodified and hybrid of modified and unmodified VP2 fragments (single strand modified). Analysis on 1\% agarose gel electrophoresis showed multiple bands of PCR products including the expected VP2 fragment of approximately $1.4 \mathrm{~kb}$ (Figure 6). SpeI digestion profile showed multiple bands produced from unmodified and modified VP2 genes. Unmodified VP2 gene was digested completely and produced $1.05 \mathrm{~kb}$ and $300 \mathrm{bp}$ band. 
Meanwhile, modified VP2 samples contained a mixture of undigested VP2 and digested VP2 fragments (Figure 7).

\section{Restriction Enzyme Analysis of Recombinant Plasmids}

Restriction enzyme analyses of non-modified (pCR2.1::VP2) and modified recombinant plasmids (pCR@8/GW::VP2Mt) with SpeI enzyme revealed only non-modified recombinant plasmid was digested by SpeI restriction enzyme. Digestion of the recombinant plasmids containing either non-modified or modified VP2 gene with EcoRI restriction enzyme produced two fragments of approximately $3.0 \mathrm{~kb}$ derived from pCR2.1/TOPO and pCR@8/GW/TOPO vectors and $1.4 \mathrm{~kb}$ of VP2 fragment. These results indicated that the recombinant pCR@8/GW::VP2Mt plasmid possess the mutated sequence of SpeI site (Figure 8).

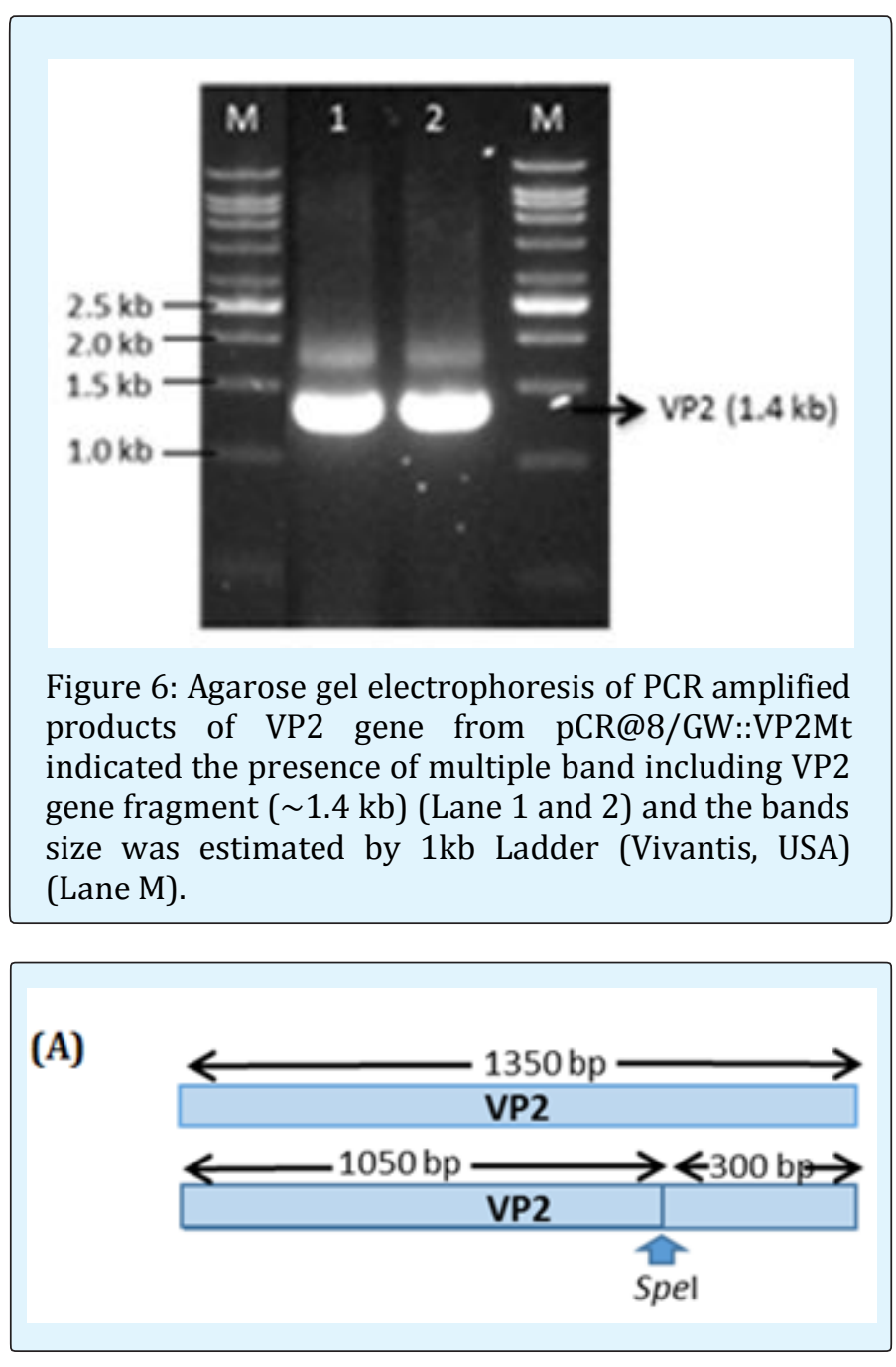

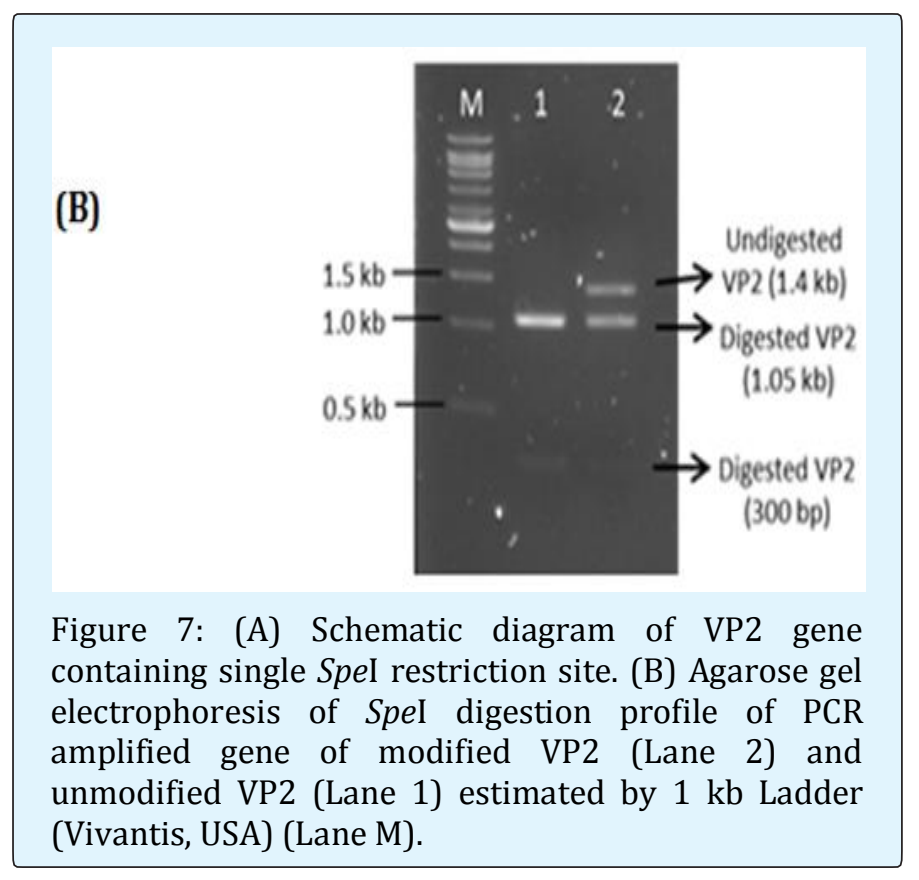

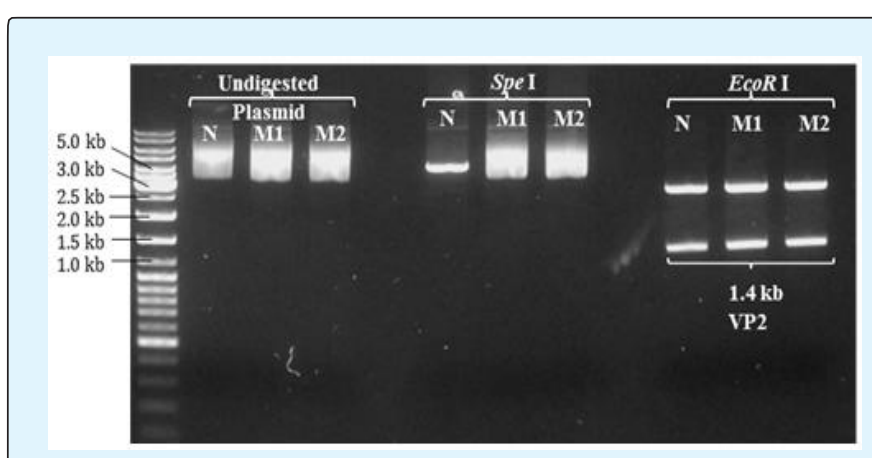

Figure 8: Restriction enzyme (RE) profile of nonmodified (pCR2.1::VP2) and modified (pCR@8/GW::VP2Mt) recombinant plasmids digested with either SpeI or EcoRI enzymes. The modified recombinant pCR@8/GW::VP2Mt plasmids (Lane M1 and M2) were not digested by SpeI as compared with non-modified pCR2.1::VP2 recombinant plasmid (Lane N). EcoRI digestion of non-modified and modified recombinant plasmids had successfully verified the presence of the cloned VP2 gene. The size of the VP2 and VP2Mt gene $(\sim 1.4 \mathrm{~kb})$ was determined based on Gene Ruler 1 kb DNA Ladder (Lane M) (Fermentas, Life Science).

\section{Linearization of Recombinant PVX::VP2Mt Vectors with SpeI Enzyme}

Digestion of recombinant PVX::VP2Mt vectors with SpeI enzyme produced linearized vectors of approximately 10 $\mathrm{kb}$ as shown in Figure 9. 


\section{Open Access Journal of Microbiology \& Biotechnology}

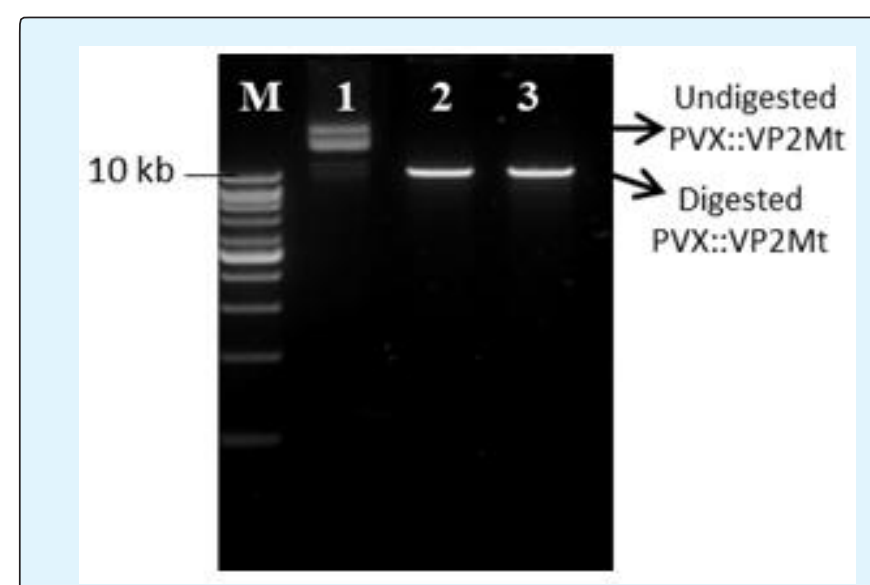

Figure 9: Restriction profiles of recombinant PVX::VP2Mt vectors digested by SpeI enzyme. Undigested recombinant PVX::VP2Mt vector (Lane 1), digested recombinant PVX::VP2Mt vector (Lane 2 and 3) and $1 \mathrm{~kb}$ DNA Ladder (Vivantis, USA).

\section{Analysis of total plant RNA and VP2 gene expression}

Analysis of total plant RNA extracted from uninfected and infected $N$. benthamiana plants indicated detection of an additional band of approximately $4.0 \mathrm{~kb}$ from RNA samples extracted from plants inoculated with empty PVX and PVX::VP2Mt as shown in Figure 10 (A). Following the inoculation of viral transcripts in N.benthamiana, the presence of VP2 gene delivered by PVX viral vector was assessed at different time interval by RT-PCR. The expected VP2 band of approximately $1.4 \mathrm{~kb}$ was detected from all samples harvested at 2, 4 and 8 dpi as shown in Figure 10 (B).

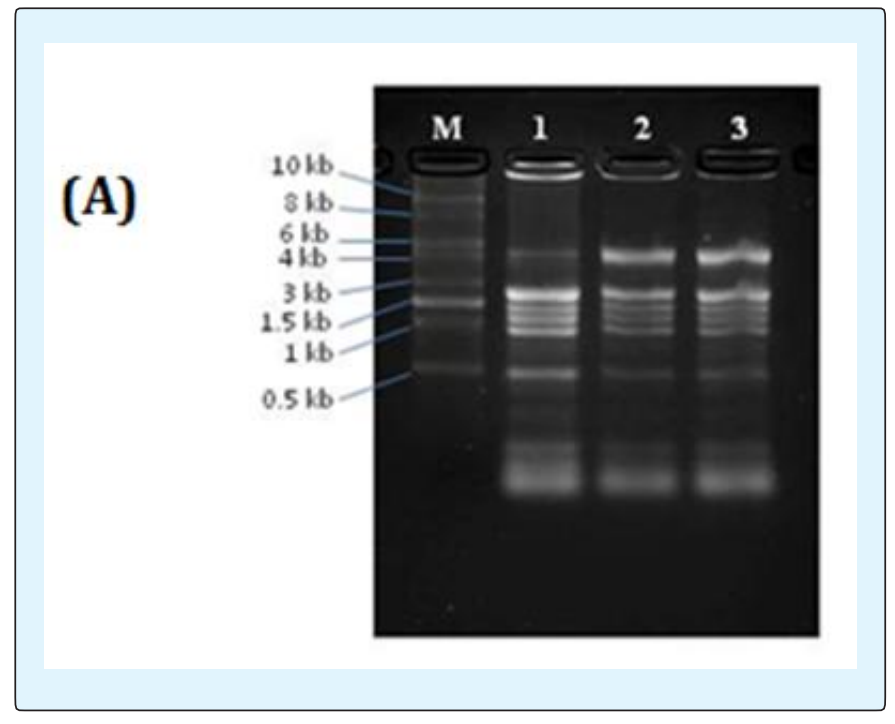

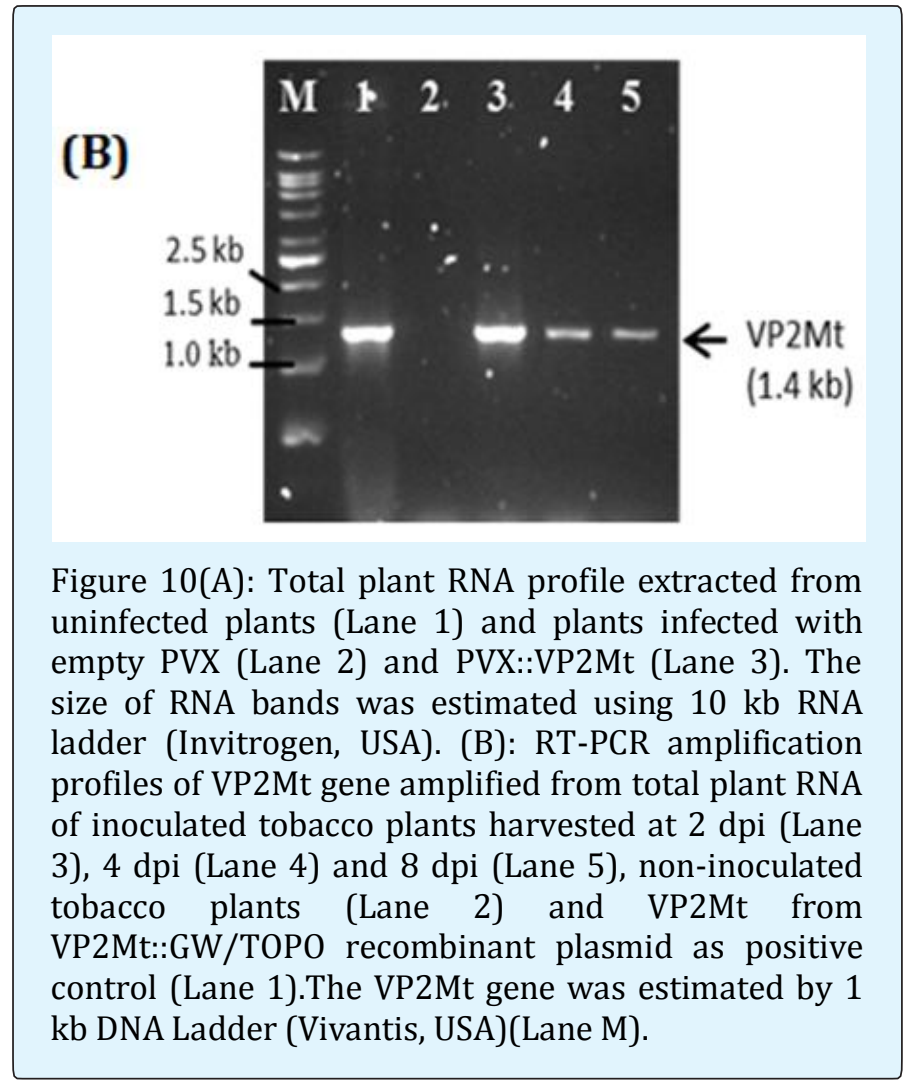

\section{Immunodetection of Expressed VP2 Protein}

Western blot analysis of total soluble protein $(15.0 \mu \mathrm{g} /$ sample) of non-inoculated leaves and inoculated leaves infected with viral transcripts $(0.25 \mu \mathrm{g} /$ leaf $)$ of empty PVX and PVX::VP2Mt harvested at 4 dpi indicated the presence of faint bands of approximately $50 \mathrm{kDa}$ from leaves inoculated with PVX::VP2Mt whereas no band was detected from leaves infected with empty PVX and noninoculated leaves (Figure 11A). The presence of expressed VP2 protein was further evaluated from plants harvested at $8 \mathrm{dpi}$ and higher concentration of total soluble protein (40 $\mu \mathrm{g} /$ sample) was employed for detection of VP2 protein by Western blot analysis. A prominent band of approximately $50 \mathrm{kD}$ was detected from total soluble protein of recombinant PVX::VP2Mt developed by chemiluminescent detection kit (Figure 11B).

\section{Kinetic Analysis of VP2 Protein Expression by Dot Blot Assay}

Kinetic analysis on the expression of VP2 protein in $N$. benthamiana based on dot blot analysis revealed detection of weak signal at $2 \mathrm{dpi}$ based on the score of level of VP2 protein expression. The expression signal started to increase at $4 \mathrm{dpi}$ and significantly increased 
from 6 dpi, maintained the level until 8 dpi and then slightly decreased at $10 \mathrm{dpi}$. The expression level was found increased when analyzed at $15 \mathrm{dpi}$ and further increased at $20 \mathrm{dpi}$. The highest level of expression was found detected at $20 \mathrm{dpi}$ but the value was reduced significantly when analyzed at $30 \mathrm{dpi}$. Table 1 summarized the above findings in the form of score value.

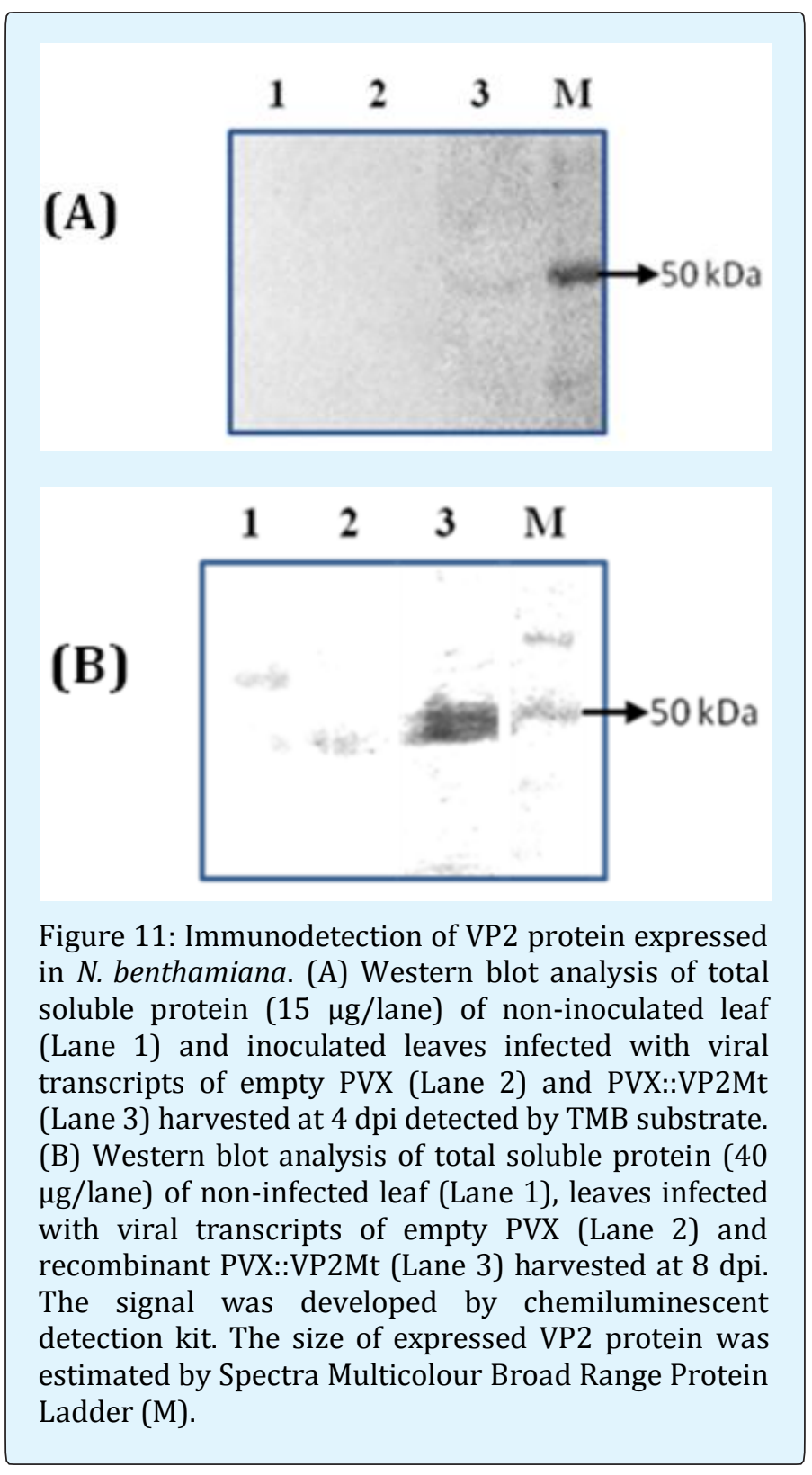

Siti-Hasmah M, et al. Single Nucleotide Modification of VP2 Gene of Highly Virulent Infectious Bursal Disease Virus for Effective Expression Strategy in Tobacco. J Microbiol Biotechnol, 2017, 2(1): 000116.

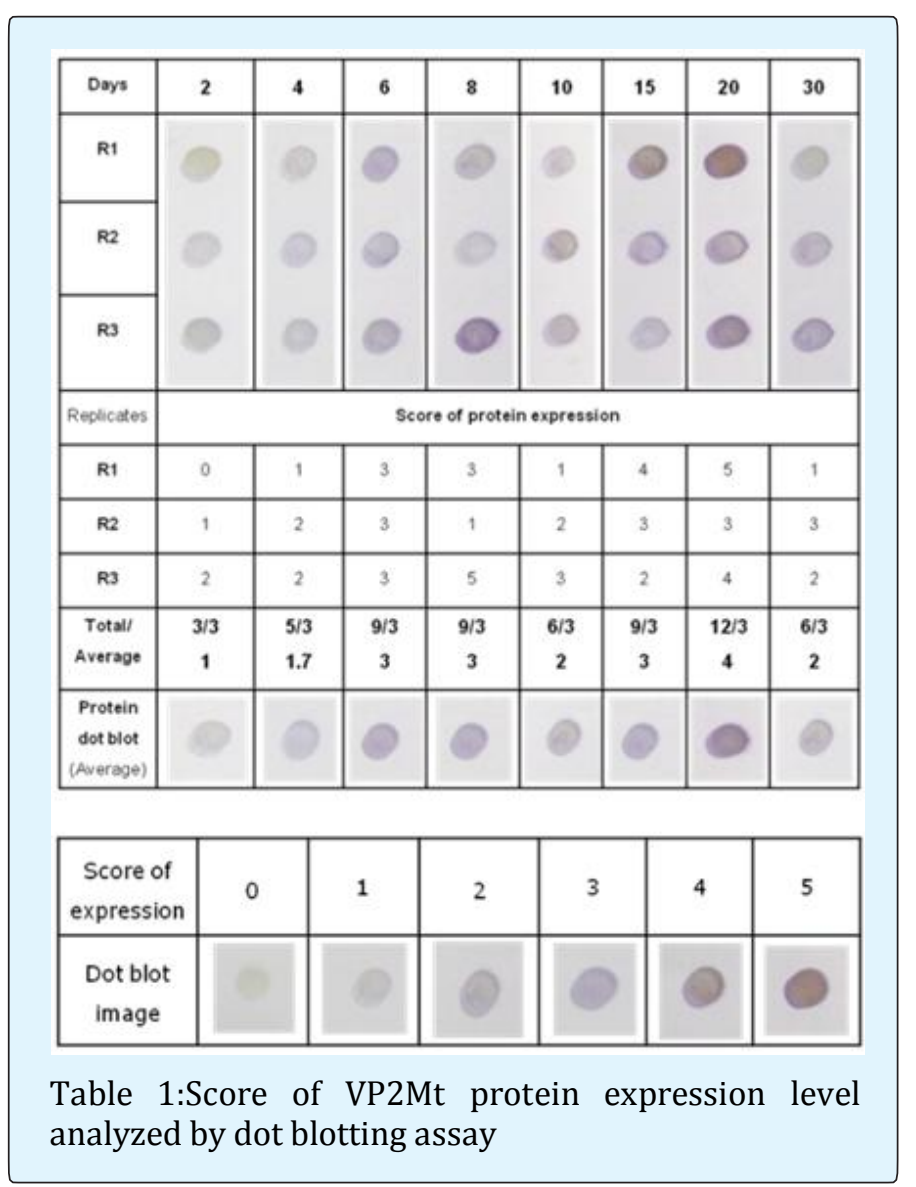

\section{Discussion}

The present study demonstrates the feasibility of a modified VP2 gene of hvIBDV to be expressed via plant viral-based expression system in tobacco. An engineered plant viral vector derived from Potato virus X (PVX) has been chosen as the gene delivery system for transient expression of the VP2 protein based on its stability and mechanically transmissible [25]. Viral infection approach has been applied to deliver the recombinant viral vector incorporated with the VP2 gene in $N$. benthamiana. This approach involves preparation of in vitro viral transcripts by generating a linearized recombinant vector through single digestion by a restriction enzyme at the unique site of the vector. In the case of recombinant PVX vector of pP2C2S incorporated with hvIBDV VP2 gene, linearization of the recombinant vector can be achieved by single digestion with SpeI or SphI restriction enzymes. Based on 


\section{Open Access Journal of Microbiology \& Biotechnology}

the previous studies, SpeI enzyme is the most preferable choice for linearization of the recombinant PVX vector compared to SphI. Digestion by SpeI enzyme was found more efficient due to its position which lies immediately downstream of the 3' poly(A) tail of the infectious clones [33]. However, the use of SpeI enzyme is only applicable if the SpeI recognition site on the VP2 coding region is disrupted into a non-functional recognition site by nucleotide modification approach. Therefore, the SpeI recognition site in the VP2 coding sequence was subjected to a single nucleotide modification in order to disrupt the SpeI site before subcloned into the expression vector of pP2C2S. The modification involves PCR amplification of the VP2 gene using a forward primer (VP2M) with a modified sequence at the SpeI site for generation of a VP2 gene (VP2Mt) containing a single nucleotide modification at the Spel site. The modification had resulted in the substitution of adenine (A) to thymine (T) without changing the amino acid leucine. The successful generation of modified VP2 gene with disrupted sequence of SpeI had facilitate the linearization process of the recombinant PVX::VP2Mt and allows generation of in vitro viral transcripts for the expression of VP2 protein in $N$. benthamiana.

PCR amplification was conducted to assess the expression of the modified VP2 gene in tobacco. Different band intensity was detected for each RNA sample whereby the highest intensity was detected from 2 dpi sample, followed by $4 \mathrm{dpi}$ and $8 \mathrm{dpi}$ with the least intensity. It can be suggested that sample harvested at 2 dpi shows the highest VP2 transcription level as compared to the other two samples. Lower band intensity demonstrated by samples of $4 \mathrm{dpi}$ and $8 \mathrm{dpi}$ was probably due to RNA recombination event that associates with removal of foreign insert of VP2 gene during viral infection $[34,37,38]$. Previous studies also reported that PVX-based chimeric viruses tend to lose the inserted foreign sequence during infection [34,39]. RNA recombination is thought to occur most frequently by a copy-choice mechanism during replication, in which the replicase dissociates from the original template and resumes polymerization, using a different RNA or a different part of the same RNA molecule as a template [40]. In RNA viruses, recombination events are frequent and likely contribute to a rapid adaptation of viruses to their hosts [41]. Foreign inserts are usually a disadvantageous load for viruses, affecting accumulation and spread, and they tend to be removed during infection as a result of selection pressure. In viral defense, the RNA silencing machinery recognizes several features of viral infections involving the formation of double-stranded (ds) RNA and initiates a process leading to the degradation of viral RNAs [42]. In this process, dsRNA is cleaved by dicer enzymes into short-interfering (si) RNA molecules (21 to 26 nucleotides in length) that guide the degradation of cognate RNAs. In productive viral infections, most viruses can counteract the RNA silencing defense, in part by expressing proteins that interfere with the RNA-silencing machinery [43,44]. Silencing of the transgene would target viral RNAs containing enough sequence similarity to the transgene for degradation, therefore inhibiting virus infection $[45,46]$.

The expressed VP2 protein was further analyzed by Western blot analyses for the confirmation of protein expression. Western blot analyses of the total soluble protein extracted from $N$. benthamiana inoculated with the viral transcripts revealed detection of protein band of approximately $50 \mathrm{kDa}$ from sample infected with recombinant PVX::VP2Mt. Analysis of low concentration of total soluble protein ( $15 \mu \mathrm{g} /$ sample) by Western blot assay indicated detection of faint band of VP2 protein developed using TMB substrate. Subsequent analysis of VP2 protein detection by Western blot assay was performed using higher concentration of total soluble protein $(40 \mu \mathrm{g} /$ sample). Detection of the expressed VP2 protein using chemiluminescent system was found able to enhance the intensity of VP2 protein band as compared to the previous analysis using TMB substrate. Improvement on the detection of VP2 protein was achieved by employing high concentration of total protein loaded onto the SDS-PAGE gel and the use of chemiluminescent system which is highly sensitive and able to detect small amount of protein. The VP2 protein of IBDV was previously expressed in rice seed and detected as a 50 $\mathrm{kDa}$ product [47]. Previous study also reported on identification of VP2 protein of approximately $50 \mathrm{kDa}$ expressed in $N$. benthamiana via agroinfiltration approach [48].

The efficacy of PVX viral-based vector to express the VP2 protein in tobacco plant was further assessed by a kinetic study of protein expression demonstrated by dot blot assay. The assessment was aimed to investigate the optimum level of protein expression starting from 2 days post-inoculation (dpi) until $30 \mathrm{dpi}$. In this analysis, the expressed VP2 protein was detected based on the formation of purple colour developed by TMB substrate. Different intensity of signal colour was given value and then used as a reference for the scoring of the expression level in dot blot assessment. Analysis on the kinetic study had found that the expression of VP2 protein can be detected at $2 \mathrm{dpi}$ and the level was increased from $4 \mathrm{dpi}$ up to $15 \mathrm{dpi}$. The highest expression level was demonstrated by protein sample analyzed at $20 \mathrm{dpi}$ and 


\section{Open Access Journal of Microbiology \& Biotechnology}

significantly decreased when reached 30 dpi. These findings showed correlations with the preliminary study on the time course assessment of VP2 gene expression whereby the VP2 gene was found viable at $2 \mathrm{dpi}$ and remained viable at $4 \mathrm{dpi}$ and $8 \mathrm{dpi}$.

A modified VP2 gene of hvIBDV was developed through a single nucleotide modification at the SpeI site and cloned onto the PVX vector for the expression of the VP2 protein in tobacco. The modification was essential to facilitate the linearization of the recombinant PVX::VP2Mt for generation of in vitro virus transcripts. Development of a modified VP2 gene allows generation of viral transcripts through single digestion of the recombinant PVX::VP2Mt at the SpeI site present in the vector. The efficacy of PVX expression vector, pP2C2S linearized by SpeI enzyme to deliver and express a modified VP2 protein was evaluated in this study. Western blot analysis of total plant crude extracts previously inoculated with PVX::VP2Mt viral transcripts demonstrates successful expression of the modified VP2 protein. Optimization of the expression conditions of VP2 protein by PVX virus based vector is essential to enhance the expression of VP2 protein at optimum level as sufficient amount of protein is required for further analysis on the immunogenicity properties of the expressed VP2 protein in animal model.

\section{Conclusion}

The present study had demonstrate an alternative strategy to facilitate the expression of VP2 gene cloned in the PVX pP2C2S vector through single nucleotide modification at the SpeI site of the VP2 gene. The VP2 protein was successfully expressed in Nicotiana benthamiana as an exogenous polypeptide protein. The time course assessments of VP2 gene expression demonstrate correlation with the kinetic analysis of the expressed VP2 protein analyzed by dot blot assay.

\section{References}

1. Dobos P, Hill BJ, Hallet R, Kells DT, Becht H, et al. (1979) Biophysical and biochemical characterization of five animal viruses with bisegmented double-stranded RNA genomes. J Virol 32(2): 593-605.

2. Murphy FA, Fauquet CM, Bishop DHL, Ghabrial SA, Jarvis AW, et al. (1995) Virus taxonomy. Classification and nomenclature of viruses. Sixth Report of the International Committee on Taxonomy of Viruses. Arch Virol Suppl 10.
3. Kibenge FSB, Dhillon AS, Russel RG (1988) Biochemistry and immunology of infectious bursal disease virus. J Gen Virol 69: 1757-1775.

4. Becht H, Muller H (1991) Infectious bursal diseaseB cell dependent immunodeficiency syndrome in chickens. Behring Inst Mitteilungen 89: 217-225.

5. Lasher HN, Shane SM (1994) Infectious bursal disease. World's Poultry Science Journal 50(2): 133166.

6. Müller H, Becht H (1982) Biosynthesis of virusspecific proteins in cells infected with infectious bursal disease virus and signification as structural elements for infectious virus and incomplete particles. Journal of Virology 44(1): 384-392.

7. Azad AA, Jagadish MN, Brown MA, Hudson PJ (1987) Deletion mapping and expression in Escherichia coli of the large genomic segment of a birnavirus. Virology 161(1): 145-152.

8. Hudson PJ, Mckern NM, Power BE, Azad AA (1986) Genomic structure of the large RNA segment of infectious bursal disease virus. Nucleic Acid Res 14(12): 5001-5012.

9. Kibenge FSB, Dhama V (1997) Evidence that virionassociated VP1 of avibirnaviruses contains viral RNA sequences. Arch Virol 142:1227-1236.

10. Fahey KJ, Erny K, Crooks J (1989) A conformational immunogen on VP2 of infectious bursal disease virus that induces virus-neutralizing antibodies that passively protect chickens. J Gen Virol 70: 14731481.

11. Becht H, Muller H, Muller HK (1988) Comparative studies on structural and antigenic properties of two serotypes of infectious bursal disease virus. J Gen Virol 69: 631-640.

12. Reddy SK, Silim A, Ratcliffe MJ (1992) Biological roles of the major capsid proteins and relationships between two existing serotypes of infectious bursal disease virus. Arch Virol 127(1-4): 209-222.

13. Omar AR, Kim CL, Hair-Bejo M, Aini I (2006) Efficacy of VP2 protein expressed in E.coli for protection against highly virulent infectious bursal disease virus. J Vet Sci 7(3): 241-247. 
14. Pei CW, Hung YS, Long HL, Der TL, Pei CY, et al. (2005) Secreted expression of the VP2 protein of very virulent infectious bursal disease virus in the methylotrophic yeast Pichia pastoris. J Virol Meth 123(2): 221-225.

15. Shaw I, Davison TF (2000) Protection from IBDVinduced bursal damage by a recombinant fowlpox vaccine, fpIBD1, is dependent on the titre of challenge virus and chicken genotype. Vaccine 18(28): 3230-3241.

16. Sheppard M, Werne RW, Tsata SE, Mcco YR, Prowse $S$, et al. (1998) Fowl adenovirus recombinant expressing VP2 of infectious bursal disease virus induces protective immunity against bursal disease. Arch Virol 143: 915-930.

17. Tsukamoto K, Kojima C, Komori Y, Tanimura N, Mase M, et al. (1999) Protection of chickens against very virulent infectious bursal disease virus (IBDV) and Marek's disease virus (MDV) with a recombinant MDV expressing IBDV VP2. Virology 257(2): 352-362.

18. Darteil R, Bublot M, Laplace E, Bouquet JF, Audonnet JC, et al. (1995) Herpes virus of turkey recombinant viruses expressing infectious bursal disease virus (IBDV) VP2 immunogen induce protection against an IBDV virulent challenge in chickens. Virology 211(2): 481-490.

19. Liu Y, Wei Y, Wu X, Lian Y (2005) Preparation of ChIL-2 and IBDV VP2 fusion protein by baculovirus expression system. Cell \& Mol Immun 2: 231-235.

20. Vakharia VN, Snyder DB, HE J, Edwards GH, Savage PK, et al. (1993) Infectious bursal disease virus structural proteins expressed in a baculovirus recombinant confer protection in chickens. J Gen Virol74: 1201-1206.

21. Chen TH, Hu CC, Liao JT, Lee CW, Liao JW, et al. (2012) Induction of protective immunity in chickens immunized with plant-made chimeric Bamboo mosaic virus particles expressing very virulent Infectious bursal disease virus antigen. Virus Research 166(1-2): 109-115.

22. Marusic C, Rizza P, Lattanzi L, Mancini C, Spada M, et al. (2001) Chimeric plant virus particles as immunogens for inducing murine and human immune responses against human immunodeficiency virus type 1. J Virol 75(18): 8434-8439.

23. Uhde K, Fischer R, Commandeur U (2005) Expression of multiple foreign epitopes presented as synthetic antigens on the surface of Potato virus X particles. Arch Virol 150(2): 327-340.

24. Baulcombe DC, Chapman S, Santa Cruz S (1995) Jellyfish green fluorescent protein as a reporter for virus infections. Plant J 7(6): 1045-1053.

25. Avesani L, Marconi G, Morandini F, Albertini E, Bruschetta M, et al. (2007) Stability of Potato virus $\mathrm{X}$ expression vectors is related to insert size: implications for replication models and risk assessment. Transgenic Res 16: 587-597.

26. Santa Cruz S, Chapman S, Roberts AG, Roberts IM, Prior DAM, et al. (1996) Assembly and movement of a plant virus carrying a green fluorescent protein overcoat. Proc Natl Acad Sci USA 93(13): 62866290.

27. Toth RL, Chapman S, Carr F, Santa Cruz S (2001) A novel strategy for the expression of foreign genes from plant virus vectors. FEBS Lett 489(2-3): 215219.

28. Ho SN, Hunt HD, Horton RM, Pullen JK, Pease LR (1989) Site-directed mutagenesis by overlap extension using the polymerase chain reaction. Gene 77(1): 51- 59 .

29. Ochman H, Gerber AS, Hartl DL (1988) Genetic applications of an inverse polymerase chain reaction. Genetics 120(3): 621-623.

30. Hemsley A, Arnheim N, Toney MD, Cortopassi G, Galas DJ (1989) A simple method for site-directed mutagenesis using the polymerase chain reaction. Nucleic Acids Res 17(16): 6545-6551.

31. Edelheit O, Hanukoglu A, Hanukoglu I (2009) Simple and efficient site-directed mutagenesis using two single-primer reactions in parallel to generate mutants for protein structure-function studies. BMC Biotechnology 9: 61.

32. Scholthof HB, Scholthof KBG, Jackson AO (1996) Plant virus gene vectors for transient expression of foreign proteins in plants. Annu Rev Phytopathol 34: 299-323. 
33. Lacomme C, Chapman S (2008) Use of Potato Virus $X$ (PVX)-Based Vectors for Gene Expression and Virus-Induced Gene Silencing (VIGS). Curr Protoc Microbiol8.

34. Chapman S, Kavanagh T, Baulcombe D (1992) Potato virus $X$ as a vector for gene expression in plants. Plant J 2(4): 549-557.

35. Mohtar SH, Loh HS, Massawe F, Omar AR (2013) Antigenicity and immunogenicity evaluations of plant-based VP2 protein of Malaysian highly virulent infectious bursal disease virus (hvIBDV) expressed in Nicotiana tabacum. IOSR Journal of Agriculture and Veterinary Science 2(6): 64-72.

36. Towbin $H$ (2009) Origins of protein blotting. In KurienBT\& ScofieldRH (Eds.), Methods in molecular biology, protein blotting and detection. Humana Press, Totowa, New Jersey 536: 1-3.

37. Guo HS, Lopez-Moya JJ, Garcia JA (1998) Susceptibility to recombination rearrangements of a chimeric plum pox potyvirus genome after insertion of a foreign gene. Virus Res 57(2): 183-195.

38. Rabindran S, Dawson WO (2001) Assessment of recombinants that arise from the use of a TMVbased transient expression vector. Virology 284(2): 182-189.

39. Gonzalez-Jara P, Atencio FA, Martinez-Garcia B, Barajas D, Tenllado F, et al. (2005) A Single Amino Acid Mutation in the Plum pox virus Helper Component-Proteinase Gene Abolishes Both Synergistic and RNA Silencing Suppression Activities. Phytopathology 95: 894-901.

40. Nagy PD, Simon AE (1997) New insights into the mechanisms of RNA recombination. Virology 235(1): 1-9.
41. Lai MM (1992) RNA recombination in animal and plant viruses. Microbiol Rev 56(1): 61-79.

42. Voinnet O (2005) Induction and suppression of RNA silencing: insights from viral infections. Nat Rev Genet 6(3): 206-220.

43. Moissiard G, Voinnet O (2004) Viral suppression of RNA silencing in plants. Mol Plant Pathol 5(1): 7182.

44. Silhavy D, Burgyan J (2004) Effects and side-effects of viral RNA silencing suppressors on short RNAs. Trends Plant Sci 9(2): 76-83.

45. Barajas D, Tenllado F, Gonzales-Jara P, MartinezGarcia B, Atencio FA, et al. (2004) Resistance to Plum pox virus (PPV) in Nicotiana benthamiana plants trasformed with the PPV HC-Pro silencing suppressor gene. Journal of Plant Pathology 86(3): 239-248.

46. Tenllado F, Díaz-Ruíz JR (2001)Double-stranded RNA-mediated interference with plant virus infection. J Virol 75(24): 12288-12297.

47. Wu J, Yu L, Li L, Hu J, Zhou J, et al. (2007) Oral immunization with transgenic rice seeds expressing VP2 protein of infectious bursal disease virus induces protective immune response in chickens. Plant Biotechnol J5(5): 570-578.

48. Gomez E, Lucero MS, Zoth SC, Carballeda JM, Gravisaco MJ, et al. (2013) Transient expression of VP2 in Nicotiana benthamiana and its use as a plant-based vaccine against Infectious Bursal Disease Virus. Vaccine 31(23): 2623-2627. 